ARTICLE

Received 25 Apr 2013 | Accepted 4 Oct 2013 | Published 11 Nov 2013

DOI: $10.1038 /$ ncomms3717

\title{
Efficient and tunable white-light emission of metal-organic frameworks by iridium-complex encapsulation
}

\author{
Chun-Yi Sun ${ }^{1, \star}$, Xin-Long Wang ${ }^{1, \star}$, Xiao Zhang ${ }^{2}$, Chao Qin ${ }^{1}$, Peng Li ${ }^{1}$, Zhong-Min Su${ }^{1}$, \\ Dong-Xia Zhu', Guo-Gang Shan ${ }^{1}$, Kui-Zhan Shao', Han Wu${ }^{1} \&$ Jing $\mathrm{Li}^{2}$
}

Metal-organic frameworks (MOFs) are well known for their tunable structure and porosity. Many studies have shown they are promising for various important applications, for which their performance can be further enhanced by encapsulating functional species, such as luminescent guest molecules, within the frameworks. Although numerous MOFs are luminescent, very few emit white light and their quantum yield is usually low. Here we report a strategy to achieve efficient white-light emission by encapsulating an iridium complex in the MOF cavity. A mesoporous blue-emitting MOF is prepared as host to encapsulate a yellowemitting iridium complex, $\left[\operatorname{lr}(\mathrm{ppy})_{2}(\mathrm{bpy})\right]^{+}$. The resultant composites emit bright white light with good colour quality (for example, Commission International de I'Eclairage coordinates, colour-rendering index and correlated colour temperature of $(0.31,0.33), 84.5$ and $5409 \mathrm{~K}$, respectively), and high quantum yield up to $115^{\circ} \mathrm{C}$. This strategy may open new perspectives for developing high-performance energy-saving solid-state lighting materials.

\footnotetext{
${ }^{1}$ Key Laboratory of Polyoxometalate, Science of Ministry of Education, Department of Chemistry, Local United Engineering Lab for Power Battery, Northeast Normal University, Changchun 130024, China. ${ }^{2}$ Department of Chemistry and Chemical Biology, Rutgers University, Piscataway, New Jersey 08854, USA

*These authors contributed equally to this work. Correspondence and requests for materials should be addressed to Z-M.S. (email: zmsu@nenu.edu.cn) or to J.L. (email: jingli@rutgers.edu).
} 
S olid-state light-emitting-diode (LED) materials have been extensively investigated in the recent years because of their potential applications in lighting and displays ${ }^{1,2}$. Currently, mercury-containing fluorescent lighting is one of the most widely used white-light sources, which relies on the emission of mercury vapour to excite semiconductor phosphors and to achieve white composite photoluminescence $(\mathrm{PL})^{3}$. However, the extensive use of mercury raises various environmental concerns. Thus tremendous efforts have been dedicated to search for environmentally more friendly, safer and more energy efficient white phosphor materials for use in the white LEDs (WLEDs) ${ }^{4-11}$, including hybrid inorganic materials ${ }^{4,5,10,11}$, rare-earth metaldoped zeolites 6 , organic compounds ${ }^{7}$, nanomaterials ${ }^{8}$ and metal complexes $^{9}$. Three types of white phosphor materials are commonly used in phosphor-based methods to generate white light, including (i) monochromatic emitters that emit in the entire visible spectrum, (ii) dichromatic emitters that blend blue and yellow light and (iii) trichromatic emitters that combine red, green and blue lights. Among them, dichromatic and trichromatic approaches have been the main focus because of their finer colour-rendering properties and higher luminescent efficiency ${ }^{12}$.

Metal - organic frameworks (MOFs) composed of metal ions and multitopic organic ligands are a new family of hybrid inorganic-organic porous materials, and have received tremendous attention in the past two decades ${ }^{13-15}$. Benefiting from uniform but tunable cavities, tailorable chemistry and high porosity, MOFs have become promising candidates for many important applications such as chemical separation ${ }^{16}$, gas storage $^{17}$, catalysis ${ }^{18}$, drug delivery ${ }^{19}$ and optical sensing/ detection $^{20}$. MOF materials possess unique advantages for luminescence-based applications primarily because of their capability of incorporating light-emissive building blocks at both metal centres and organic ligands. This allows efficient modulation of luminescent properties. In addition, permanent porosity in these structures permits the accommodation of guest molecules within their frameworks, offering another degree of tunability in their emission properties ${ }^{21}$. Through judicious choice of metal centres and organic linkers, a large number of luminescent MOFs have been synthesized (accounting for $>10 \%$ of the total number of reported MOFs) and their possible applications in fluorescent sensors, nonlinear optics, photocatalysis and biomedical imaging have been evaluated ${ }^{22}$. On the other hand, it remains a great challenge to produce highperformance white-emitting MOF materials suitable for solidstate lighting applications. To date, only a few examples of direct white-light-emitting MOFs are realized ${ }^{23-26}$. Doping the framework structures by rare metals (for example, $\mathrm{Eu}^{3+}$, $\mathrm{Tb}^{3+}$ and $\mathrm{Dy}^{3+}$ ) at various concentrations may lead to white light ${ }^{12,27-29}$, but at low quantum yield ${ }^{12}$. Thus, it is essential to develop an effective method to obtain highly efficient, white-lightemitting MOF materials.

Herein, we introduce a new strategy to achieve high quantum yield white light by encapsulating a yellow-emitting Ir $^{\text {III }}$ complex in the cavity of a blue-emitting MOF. Ir ${ }^{\mathrm{III}}$ complexes are well known for their high PL efficiency, relatively short lifetimes and emissive light variety ${ }^{30}$. Large-pore MOF structures with tunable pore sizes (up to $9.8 \mathrm{~nm}$ (ref. 31)) may be constructed by suitable choice of organic ligands of various length which will ensure the entrapment of Ir $^{\mathrm{III}}$ complexes in large quantity. Thus, it may be anticipated that a successful encapsulation of yellow-emitting Ir $^{\mathrm{III}}$ complex in a blue-emitting MOF will not only produce white light, but also generate high quantum yield, because the aggregation of $\mathrm{Ir}^{\mathrm{III}}$ complexes can be effectively prevented and their oscillation may also be effectively constrained when confined into the MOF pores ${ }^{32}$. A cationic $\mathrm{Ir}^{\mathrm{III}}$ complex,
$\left[\operatorname{Ir}(\text { ppy })_{2}(\text { bpy })\right]^{+}\left(\right.$Hppy $=2$-phenylpyridine, bpy $=2,2^{\prime}$-bipyridine $)$, was selected in this study as an encapsulate for its relatively small size which allows easy access to the MOF pores. Hexadentate carboxylate triazine ligand, 2,4,6-tris(2,5-dicarboxylphenylamino)-1,3,5-triazine ( $\mathrm{H}_{6}$ TATPT, Supplementary Fig. S1) was chosen as the organic building block to construct highly porous blue-light-emitting MOF, based on the following considerations: (i) it has a suitable length for building MOF structures with desired pore diameters ${ }^{33,34}$, (ii) it offers multiple metal binding modes and (iii) it emits at $490 \mathrm{~nm}$ which will likely result in a blue-emitting MOF material. Cadmium ion was selected as metal centre because $\mathrm{d}^{10}$ metal ions not only possess various coordination numbers and geometries, but also exhibit photoactive capability when bound to functional ligands ${ }^{35}$. With TATPT and $\mathrm{Cd}^{2+}$, we successfully prepared a threedimensional (3D) mesoporous blue-emitting anionic MOF, $\left[\left(\mathrm{CH}_{3}\right)_{2} \mathrm{NH}_{2}\right]_{15}\left[\left(\mathrm{Cd}_{2} \mathrm{Cl}\right)_{3}(\mathrm{TATPT})_{4}\right] \cdot 12 \mathrm{DMF} \cdot 18 \mathrm{H}_{2} \mathrm{O}$ (1) which contains two types of cages with the dimensions of approximate 2 and $3 \mathrm{~nm}$. Compound 1 emits bright blue light $\left(\lambda_{\mathrm{em}}=425 \mathrm{~nm}\right)$ attributed to the emissive organic TATPT linker. $\left[\operatorname{Ir}(\mathrm{ppy})_{2}(\mathrm{bpy})\right]^{+}$was successfully loaded into the pores of 1 to form $\left[\operatorname{Ir}(\mathrm{ppy})_{2}(\mathrm{bpy})\right]^{+} @ \mathbf{1}$ at various concentrations. The new composite emitter generates bright white light when excited at $370 \mathrm{~nm}$ with a quantum yield as high as $20.4 \%$. This value is the highest among all white-light-emitting MOF materials reported to date ${ }^{12,23-29}$ and is approaching the level of the best inorganicorganic hybrid semiconductor bulk materials ${ }^{36}$. At an $\left[\operatorname{Ir}(\text { ppy })_{2}(\text { bpy })\right]^{+}$concentration of $3.5 \mathrm{wt} \%$, the Commission International de I'Eclairage (CIE) coordinates, colour-rendering index (CRI) and correlated colour temperature (CCT) values were calculated to be $(0.31,0.33), 80$ and $5900 \mathrm{~K}$, respectively. A WLED assembly built on an ultraviolet LED chip (InGaAsN, $370 \mathrm{~nm})$ and an $\left[\operatorname{Ir}(\mathrm{ppy})_{2}(\mathrm{bpy})\right]^{+} @ 1$ sample at $3.8 \mathrm{wt} \%$ of $\mathrm{Ir}-$ complex yielded $(0.30,0.35), 84.5$ and $5409 \mathrm{~K}$ for CIE, CRI and $\mathrm{CCT}$, respectively.

\section{Results}

$\mathrm{X}$-ray diffraction analysis of compound 1. Compound 1 was synthesized by reacting $\mathrm{H}_{6}$ TATPT and $\mathrm{CdCl}_{2} \cdot 2.5 \mathrm{H}_{2} \mathrm{O}(1: 1$ molar ratio) in a $\mathrm{N}, \mathrm{N}$-dimethylformamide (DMF)/MeOH solvent mixture heated at $120^{\circ} \mathrm{C}$ for 2 days. The reaction produced colourless crystals with polyhedral morphology (Supplementary Fig. S2). The phase purity of $\mathbf{1}$ was confirmed by powder X-ray diffraction (PXRD) analysis. The formula of $\mathbf{1}$ was obtained by single-crystal $\mathrm{X}$-ray diffraction, elemental analysis (EA), thermogravimetric analysis (TGA) and by taking into account charge balance considerations. The protonated $\left[\left(\mathrm{CH}_{3}\right)_{2} \mathrm{NH}_{2}\right]^{+}$is a result of decomposition of $\mathrm{DMF}^{37}$.

Single-crystal X-ray diffraction analysis reveals that $\mathbf{1}$ is a $3 \mathrm{D}$ non-interpenetrated framework. It crystallizes in cubic space group Fm-3m (Supplementary Table S1). The asymmetric unit of 1 contains one crystallographically independent cadmium ion, one chlorine ion and one-sixth of TATPT ligand. Other disordered cations and guest molecules are not crystallographically well defined. Compound $\mathbf{1}$ is built on a cuboid $\mathrm{Cd}_{2}\left(\mu_{2}-\right.$ $\mathrm{Cl})\left(\mathrm{CO}_{2}\right)_{8}$ secondary building unit $(\mathrm{SBU})$. In this $\mathrm{SBU}$, the two $\mathrm{Cd}$ atoms are nine-coordinated by a $\mu_{2}-\mathrm{Cl}$ and eight carboxylate oxygen atoms from four TATPT ligands in enneahedral geometry (Supplementary Fig. S3a). The $\mu_{2}-\mathrm{Cl}$ atom connects the two $\mathrm{Cd}$ atoms lying at the centre of the rectangular parallelepiped. The bond lengths of $\mathrm{Cd}-\mathrm{O}$ carboxylate (2.285-2.646 $\mathrm{A})$ are within the normal range of those reported cadmium-carboxylate compounds and the bond lengths of $\mathrm{Cd}-\mathrm{Cl}(2.699 \AA)$ are close to the reported cadmium-chlorine compounds. Each SBU is eight-coordinated to four TATPT ligands, and each TATPT is 
a
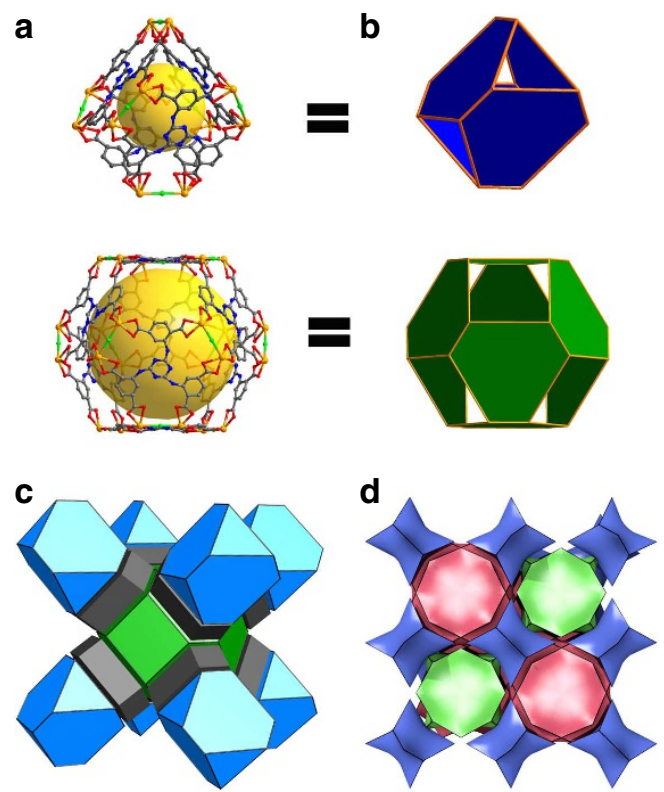

Figure 1 | Structure of 1 determined by single-crystal XRD. (a) Ball and stick representations of the truncated tetrahedral and truncated octahedral cages, the yellow spheres represent the void inside the cages. (b) Polyhedral presentation of a. (c) The 3D polyhedral structure of 1. (d) The $(3,4)$-connected augmented net (top) as a natural tiling.

six-connected to three SBUs (Supplementary Fig. S3b) to form a truncated tetrahedron $^{38}$ (Fig. 1a), in which all six vertices are occupied by the SBUs, and four of the hexagonal faces are held by TATPT ligands. The dimension of the truncated tetrahedral cage is $19.2 \times 16.7 \times 16.3 \AA^{3}$ (measured between opposite atoms and van der Waals radii of the atoms are not taken into account) and the size of windows is about $11 \times 11 \AA^{2}$. Eight such truncated tetrahedrons occupy the eight vertices of a cube, resulting in a mesoporous truncated octahedron ${ }^{38}$ (Fig. 1b) through corner sharing. The dimensions of this truncated octahedron are $27.2 \times 23.1 \times 27.2 \AA^{3}$ with a window size of $\sim 15.5 \times 15.5 \AA^{2}$. The truncated octahedra propagate to form a three-dimensional non-interpenetrated extended open network (Fig. 1c and Supplementary Fig. S3). The pore structure can also be viewed as three intersecting1D channels with a window size of $15.5 \times 15.5 \AA^{2}$. From the topological point of view, each of the $\mathrm{Cd}_{2}\left(\mu_{2}-\mathrm{Cl}\right)\left(\mathrm{CO}_{2}\right)_{8} \mathrm{SBU}$ acts as a four-connected node and every TATPT ligand serves as a three-connected node, thus the framework can be described as a binodal $(3,4)$-connected $3 \mathrm{D}$ network with tbo topology (Schläfli symbol $\left.\left(6^{2} \cdot 8^{2} \cdot 10^{2}\right)_{3}\left(6^{3}\right)_{4}\right)$ (Fig. 1d). The solvent molecules and $\left[\left(\mathrm{CH}_{3}\right)_{2} \mathrm{NH}_{2}\right]^{+}$cations reside in the channels. The effective free volume of $\mathbf{1}$, calculated by PLATON software ${ }^{39}$, is $67.8 \%$ of the crystal volume $\left(38,769.5 \AA^{3}\right.$ of the $57,186.8 \AA$ unit cell volumes), upon removal of the guest molecules.

TGA and transition metal ion exchange experiments. Overall, the framework structure is anionic with $\mathrm{H}_{2} \mathrm{O}$ molecule, $\left(\mathrm{CH}_{3}\right)_{2} \mathrm{NH}_{2}^{+}$cations as well as DMF residing in the channels, as determined by EA, TGA and by the consideration of charge balance. The TGA data (Supplementary Fig. S4) reveal that the first weight loss corresponds to the loss of solvent and water molecules $(20.3 \mathrm{wt} \%)$. The desolvated framework remains stable until $\sim 210^{\circ} \mathrm{C}$ (Supplementary Fig. S4). The decomposition of the framework began to take place at this temperature. The final residue is CdO (observed 16.0\%, calculated 15.1\%). Furthermore, transition metal cation exchange experiments were performed by soaking samples of 1 in solutions of $\mathrm{Cu}\left(\mathrm{NO}_{3}\right)_{2} \cdot 3 \mathrm{H}_{2} \mathrm{O}, \mathrm{Co}(\mathrm{N}$ $\left.\mathrm{O}_{3}\right)_{2} \cdot 6 \mathrm{H}_{2} \mathrm{O}, \mathrm{Ni}\left(\mathrm{NO}_{3}\right)_{2} \cdot 6 \mathrm{H}_{2} \mathrm{O}$ and $\mathrm{Zn}\left(\mathrm{NO}_{3}\right)_{2} \cdot 6 \mathrm{H}_{2} \mathrm{O}$ in DMF solvent, respectively. After a few days the colour of the solid changed from colourless to teal, red and light green, for $\mathrm{Cu}^{2+}$, $\mathrm{Co}^{2+}$ and $\mathrm{Ni}^{2+}$, respectively (Supplementary Fig. S5). For $\mathrm{Zn}\left(\mathrm{NO}_{3}\right)_{2}$, no colour change was observed. A PXRD comparison of $\mathbf{1}$ before and after exchange experiments indicates that the integrity of $\mathbf{1}$ is retained after transition metal cation exchange uptake (Supplementary Fig. S6). The successful exchange of $\left(\mathrm{CH}_{3}\right)_{2} \mathrm{NH}_{2}^{+}$with transition metal cations was confirmed by ${ }^{1} \mathrm{H}$ NMR spectroscopic studies after cation exchange experiments (Supplementary Fig. S7). The products were characterized by Inductively coupled plasma (ICP) spectroscopy (Supplementary Table S2) and the results show that approximately $0.46 \mathrm{Cu}^{\mathrm{II}}, 0.37$ $\mathrm{Co}^{\mathrm{II}}, 0.26 \mathrm{Ni}^{\mathrm{II}}$ and $0.28 \mathrm{Zn}^{\mathrm{II}}$ per formula was impregnated into the framework.

PL measurements of $\mathrm{H}_{6}$ TATPT and compound 1. The emission spectra of the $\mathrm{H}_{6}$ TATPT ligand, and compound $\mathbf{1}$ in powder form were measured at room temperature and displayed in Supplementary Fig. S8. The free $\mathrm{H}_{6}$ TATPT ligand exhibits a weak emission at $490 \mathrm{~nm}$ under the excitation at $370 \mathrm{~nm}$, which is due presumably to the $\pi \rightarrow \pi^{*}$ transition of the intraligands ${ }^{40}$. Upon excitation at the same wavelength, compound 1 shows significantly enhanced bright blue light emission with an emission maximum at $425 \mathrm{~nm}$ (Supplementary Fig. S9) ${ }^{41}$. Compared with the free organic linker, the large enhancement of emission intensity and strong blue shift (about $65 \mathrm{~nm}$ ) of the emission in $\mathbf{1}$ may be attributed to metal-to-ligand charge transfer (MLCT) and the coordination effects of the ligand to Cd (II) cations, which increases the ligand conformational rigidity and reduces the non-radiative decay ${ }^{42}$. The CIE coordinates for the blue emission of compound 1 was calculated to be $(0.175,0.145)$, close to that of saturated blue emitter with CIE coordinates of $(0.14,0.08)^{43}$. The quantum yield of compound 1 was measured under $\lambda_{\mathrm{ex}}=370 \mathrm{~nm}$ at room temperature and a value of $15.1 \%$ was obtained. These data demonstrate that compound $\mathbf{1}$ is an efficient blue-light emitter ${ }^{44}$.

Encapsulating $\left[\operatorname{Ir}(\text { ppy })_{2}(\text { bpy })\right]^{+}$in compound 1. Primary $\operatorname{Ir}^{\mathrm{III}}$ complex, $\left[\operatorname{Ir}(\mathrm{ppy})_{2}(\mathrm{bpy})\right]^{+}$(with a counter ion $\left.\left[\mathrm{PF}_{6}\right]^{-}\right)$, was selected as the encapsulant ${ }^{45}$. With a molecular size of $\sim 10 \times 11 \AA^{2}$ which is smaller than the aperture of the pore windows of compound $\mathbf{1}$, the complex can enter the pores readily. The $\left[\operatorname{Ir}(\mathrm{ppy})_{2}(\mathrm{bpy})\right]\left[\mathrm{PF}_{6}\right]$ complex was synthesized according to the reported procedure ${ }^{46}$ and its structure is shown in Fig. 2. The emission spectrum of $\left[\operatorname{Ir}(\mathrm{ppy})_{2}(\mathrm{bpy})\right]\left[\mathrm{PF}_{6}\right]$ was measured in DMF solution at room temperature and plotted in Supplementary Fig. S10. From the emission spectrum it is clear that when excited at $370 \mathrm{~nm},\left[\operatorname{Ir}(\mathrm{ppy})_{2}(\mathrm{bpy})\right]\left[\mathrm{PF}_{6}\right]$ emits yellow light with broad and structureless emission at $570 \mathrm{~nm}$, indicating a predominant ${ }^{3}$ MLCT or ${ }^{3}$ LLCT character ${ }^{47,48}$.

In an initial attempt, powder samples of $\mathbf{1}$ were immersed into DMF solutions of $\left[\operatorname{Ir}(\mathrm{ppy})_{2}(\mathrm{bpy})\right]^{+}\left(10^{-4} \mathrm{~mol} \cdot \mathrm{1}^{-1}\right)$ in duplicate. After 7 and 10 days, both soaked samples were removed from the solution. An obvious colour change from colourless to light yellow was observed, indicative of a successful encapsulation of $\left[\operatorname{Ir}(\text { ppy })_{2}(\mathrm{bpy})\right]^{+}$into the framework of compound 1. As evidenced from the PXRD data, the $\left[\operatorname{Ir}(\mathrm{ppy})_{2}(\mathrm{bpy})\right]^{+} @ \mathbf{1}$ samples maintain their crystallinity (Supplementary Fig. S11). The concentrations of encapsulated $\left[\operatorname{Ir}(\mathrm{ppy})_{2}(\mathrm{bpy})\right]^{+}$were measured by ICP experiment. The results show that $\sim 7.5 \mathrm{wt} \%$ and $\sim 8.8 \mathrm{wt} \%\left[\operatorname{Ir}(\mathrm{ppy})_{2}(\mathrm{bpy})\right]^{+}$were embedded, respectively, with respect to Cd. PL spectra were collected on both 


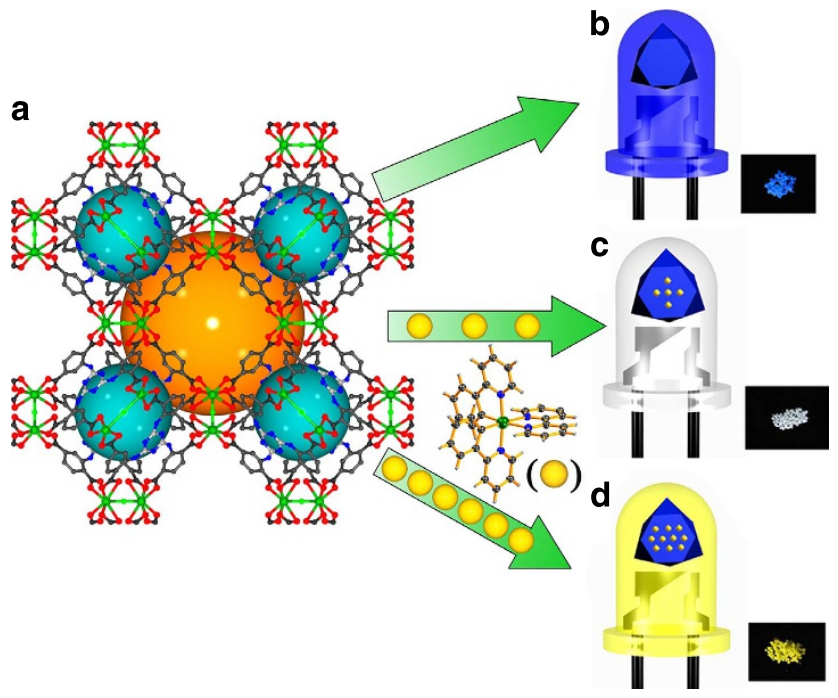

Figure 2 | Scheme of the encapsulation of $\left[\operatorname{Ir}(\text { ppy })_{2}(\text { bpy })\right]^{+}$in compound 1. (a) Ball and stick representations of the $3 D$ structure of $\mathbf{1}$, the orange and dark cyan spheres represent the void inside the cages. (b) When radiated under a standard laboratory ultraviolet lamp $(365 \mathrm{~nm})$, compound $\mathbf{1}$ emits bright blue light. (c,d) $\left[\operatorname{lr}(\mathrm{ppy})_{2}(\mathrm{bpy})\right]^{+}$- encapsulated samples $\left[\operatorname{lr}(\mathrm{ppy})_{2}(\mathrm{bpy})\right]^{+} @ \mathbf{1}$ emit bright white (3.5wt\%) and yellow (8.8 wt\%) light, respectively, using the same $365 \mathrm{~nm}$ ultraviolet lamp.

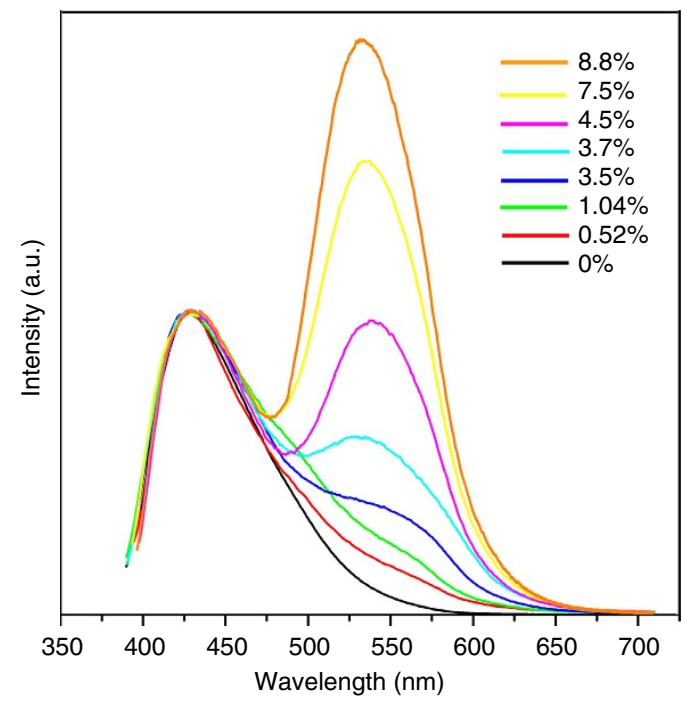

Figure 3 | PL spectra of 1 and $\left[\operatorname{Ir}(\text { ppy })_{2} \text { (bpy) }\right]^{+}$encapsulated 1. Room temperature emission spectra of $\mathbf{1}$ and $\left[\operatorname{lr}(\mathrm{ppy})_{2}(\mathrm{bpy})\right]^{+} @ \mathbf{1}$ with different concentration of $\left[\operatorname{lr}(\text { ppy })_{2}(\text { bpy })\right]^{+}$: black, emission spectrum of $\mathbf{1}$; red, $0.52 \mathrm{wt} \%\left[\operatorname{Ir}(\mathrm{ppy})_{2} \text { (bpy) }\right]^{+}$at 1; green, $1.04 \mathrm{wt} \%$; blue, $3.5 \mathrm{wt} \%$; cyan, $3.7 \mathrm{wt} \%$; pink, $4.5 \mathrm{wt} \%$; yellow, $7.5 \mathrm{wt} \%$; orange, $8.8 \mathrm{wt} \%$. All measurements were performed on solid samples at an excitation wavelength $\left(\lambda_{\mathrm{ex}}\right)$ of $370 \mathrm{~nm}$.

$\left[\operatorname{Ir}(\text { ppy })_{2}(\text { bpy })\right]^{+} @ 1$ samples. As shown in Fig. 3 (yellow and orange curves), the PL spectra of both samples exhibit two emission maxima at $\sim 425$ and $\sim 530 \mathrm{~nm}$, respectively, when irradiated at $370 \mathrm{~nm}$. The emission at $425 \mathrm{~nm}$ is attributed to MLCT in 1 whereas the emission at $530 \mathrm{~nm}$ presumably originates from $\left[\operatorname{Ir}(\mathrm{ppy})_{2}(\mathrm{bpy})\right]^{+}$. However, in comparison with the emission of free $\left[\operatorname{Ir}(\mathrm{ppy})_{2}(\mathrm{bpy})\right]^{+}$, there is an obvious blue shift (about $40 \mathrm{~nm}$ ) in the emission spectra of the

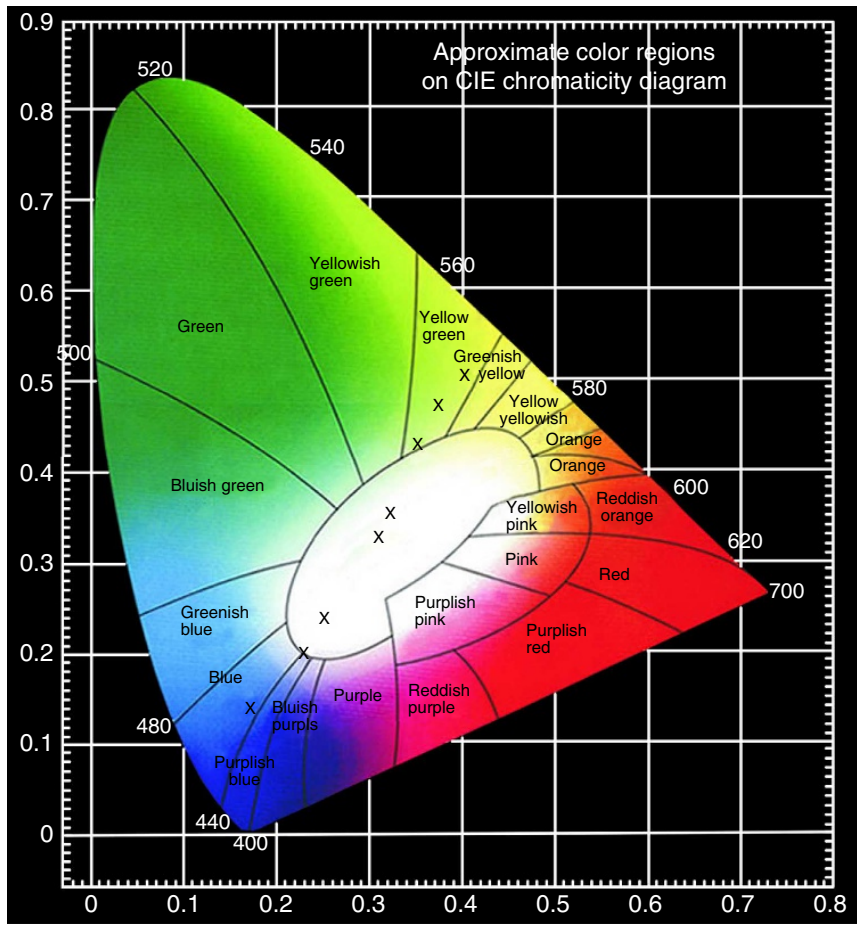

Figure 4 | CIE-1931 chromaticity diagram. The CIE coordinates (marked by the crosses) for $\mathbf{1}$ and $\left[\operatorname{lr}(\mathrm{ppy})_{2}(\mathrm{bpy})\right]^{+} @ \mathbf{1}$ at various concentrations of $\left[\operatorname{lr}(\mathrm{ppy})_{2}\right.$ (bpy)] $\left(\lambda_{\mathrm{ex}}=370 \mathrm{~nm}\right)$.

$\left[\operatorname{Ir}(\text { ppy })_{2}(\text { bpy })\right]^{+} @ 1$ composites. A possible explanation for such large blue shift is that the confinement of $\left[\operatorname{Ir}(\text { ppy })_{2}(\text { bpy })\right]^{+}$ within the pores of $\mathbf{1}$ leads to a phenomenon very similar to a 'rigidochromic effect' reported and explained previously on similar metal complexes ${ }^{49-51}$. The corresponding CIE coordinates were calculated and the values are $(0.37,0.47)$ and $(0.40,0.50)$ for $7.5 \mathrm{wt} \%$ and $8.8 \mathrm{wt} \%$ encapsulated samples, respectively, at an excitation wavelength $\left(\lambda_{\mathrm{ex}}\right)$ of $370 \mathrm{~nm}$. The quantum yield of the $8.8 \mathrm{wt} \%\left[\operatorname{Ir}(\mathrm{ppy})_{2}(\mathrm{bpy})\right]^{+} @ \mathbf{1}$ sample was measured at room temperature. A value of $28.7 \%$ was achieved at $\lambda_{\mathrm{ex}}=370 \mathrm{~nm}$. The photograph of its emission is shown in Fig. 2d, Supplementary Fig. S12c and Supplementary Fig. S13, excited at $365 \mathrm{~nm}$ using an ultraviolet lamp. Another interesting phenomenon observed in the PL spectra is that the intensity of the $530 \mathrm{~nm}$ emission is higher for the $8.8 \mathrm{wt} \%$ than for the $7.5 \mathrm{wt} \%$ encapsulated sample, whereas the intensity of $425 \mathrm{~nm}$ emission is similar for the two samples. This is another evidence that the $530 \mathrm{~nm}$ emission is due to $\left[\operatorname{Ir}(\text { ppy })_{2}(\text { bpy })\right]^{+}$.

Fabrication of WLEDs of $\left[\operatorname{Ir}(\mathrm{ppy})_{2}(\mathrm{bpy})\right]^{+} @ 1$ composite. To obtain white-light emission, a more balanced distribution of the two emissions is needed. This can be accomplished by reducing the amount of $\left[\operatorname{Ir}(\mathrm{ppy})_{2}(\mathrm{bpy})\right]^{+}$in compound 1 . The corresponding PL spectra of $\left[\operatorname{Ir}(\text { ppy })_{2}(\text { bpy })\right]^{+}$encapsulated samples at different concentrations were collected and plotted in Fig. 3. The PL spectra show that the intensity of the emission at $530 \mathrm{~nm}$ decreases monotonically as the $\left[\operatorname{Ir}(\text { ppy })_{2}(\text { bpy })\right]^{+}$amount decreases. White-light emission was achieved as the concentration of Ir complex was adjusted from $1.04 \mathrm{wt} \%$ to $3.7 \mathrm{wt} \%$ (see Fig. 4, and Supplementary Table S3). The optimal concentration for the white light was found to be $3.5 \mathrm{wt} \%$, with CIE coordinates of $(0.31,0.33)$. This is very close to those of the pure white light $(0.33,0.33)$. Other related colour parameters, including the CCT and CRI, were also estimated. At this concentration, these values 
are $\sim 80$ and $\sim 5,900 \mathrm{~K}$, respectively. The quantum yield was measured and a value up to $20.4 \%$ was obtained $\left(\lambda_{\mathrm{ex}}=370 \mathrm{~nm}\right)$ for this sample. This value is the highest among all reported white-light-emitting MOFs ${ }^{12,23-29}$ to this date (Supplementary Table S4), and is approaching that of the best inorganic-organic hybrid semiconductor white-light emitters ${ }^{36}$. Photographs showing white-light emission of a 3.5 wt $\%\left[\operatorname{Ir}(\mathrm{ppy})_{2}(\mathrm{bpy})\right]^{+} @ 1$ sample under radiation at $365 \mathrm{~nm}$ (ultraviolet lamp) are given in Fig. 2b and Supplementary Fig. S12.

Clearly, the observed broad emission of $\left[\operatorname{Ir}(\text { ppy })_{2}(\mathrm{bpy})\right]^{+} @ \mathbf{1}$ is simply a combination of the two independent emissive component, $\left[\operatorname{Ir}(\mathrm{ppy})_{2}(\mathrm{bpy})\right]^{+}$and $\mathbf{1}$. Such an additive behaviour is possible when there is essentially no energy and electron/charge transfer between the two species. This is evident from the absorption and emission spectra of the individual components ${ }^{52}$ (Supplementary Figs S14 and S15) and the fact that the second emission peak of $\left[\operatorname{Ir}(\mathrm{ppy})_{2}(\mathrm{bpy})\right]^{+} @ \mathbf{1}$ is independent from the first and is a monotonic function of Ir concentration (Fig. 3). To further verify this, we have carried out lifetime measurements on 1 and $\left[\operatorname{Ir}(\text { ppy })_{2}(\text { bpy })\right]^{+} @ 1$ at $\lambda_{\mathrm{ex}}=370 \mathrm{~nm}$ and $\lambda_{\mathrm{em}}=425 \mathrm{~nm}$ by time-correlated single photon counting. The results show that compound 1 exhibits single-exponential decay behaviour with a lifetime of $\sim 0.84 \mathrm{~ns}$ (Supplementary Fig. S16). The lifetime is 0.77 and $0.75 \mathrm{~ns}$ for the 3.5 and $8.8 \mathrm{wt} \%$ of $\left[\operatorname{Ir}(\mathrm{ppy})_{2}(\mathrm{bpy})\right]^{+} @ \mathbf{1}$, respectively). These data indicate that the lifetimes of $\mathbf{1}$ and $\left[\operatorname{Ir}(\text { ppy })_{2}(\text { bpy })\right]^{+}$encapsulated samples remain little affected, and thus, confirming that there is no energy transfer between the two components $\left(\left[\operatorname{Ir}(\text { ppy })_{2}(\text { bpy })\right]^{+} \text {and } \mathbf{1}\right)^{53}$.

To evaluate the temperature effect on the emission, PL spectra (Supplementary Fig. S17) and quantum yield (Supplementary Table S5) of $\left[\operatorname{Ir}(\mathrm{ppy})_{2}(\mathrm{bpy})\right]^{+} @ 1$ were collected at various temperatures. As shown in Supplementary Fig. S17, the intensity of the yellow emission $(530 \mathrm{~nm})$ is essentially unaffected over the entire temperature range investigated. For blue emission $(425 \mathrm{~nm})$, a very small change is observed below $115^{\circ} \mathrm{C}$. Above this temperature, the emission intensity and consequently, quantum yield, are reduced considerably. At $150^{\circ} \mathrm{C}$, a $\sim 40 \%$ loss is observed (Supplementary Fig. S17). This is due to the partial degradation of the MOF framework upon heating at high temperatures. Thus, $\left[\operatorname{Ir}(\mathrm{ppy})_{2}(\mathrm{bpy})\right]^{+} @ \mathbf{1}$ is relatively stable only below $115^{\circ} \mathrm{C}$.

WLED assemblies using this material were fabricated by two methods. The first one employed a commercially available ultraviolet LED (similar to the reported procedure ${ }^{36}$ ) and an $\left[\operatorname{Ir}(\text { ppy })_{2}(\text { bpy) }]^{+} @ 1\right.$ sample (Ir complex: 3.5 wt\%) as phosphor. The resultant WLED exhibits bright white light at an applied voltage of $3.8 \mathrm{~V}$ (see Fig. 5). The second WLED was made by an InGaAsN chip $(370 \mathrm{~nm})$ and an $\left[\operatorname{Ir}(\mathrm{ppy})_{2}(\mathrm{bpy})\right]^{+} @ \mathbf{1}$ sample at an $\left[\operatorname{Ir}(\mathrm{ppy})_{2}(\mathrm{bpy})\right]^{+}$concentration of $3.8 \mathrm{wt} \%$ (Supplementary

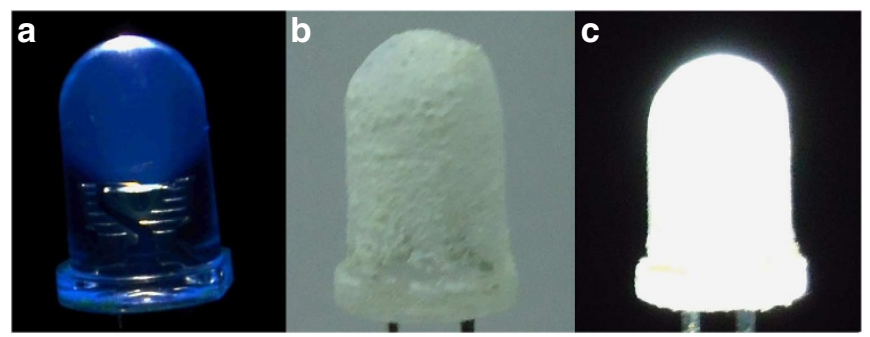

Figure 5 | Photographs of the LEDs. (a) An illuminating $3 \mathrm{~mm}$ reference ultraviolet LED (turned-on emission has a blue tinge). (b) The same LED coated with a thin layer of sample of $3.5 \mathrm{wt} \%\left[\operatorname{lr}(\mathrm{ppy})_{2}(\mathrm{bpy})\right]^{+} @ \mathbf{1}$ (not turned on). (c) The coated LED was turned on and illuminates bright white light.
Fig. S18). The latter yielded a CIE, CCT and CRI values of (0.30, 0.35 ), 84.5 and $5409 \mathrm{~K}$ (Supplementary Table S6), respectively. On the basis of these results, it is clear that the $\left[\operatorname{Ir}(\mathrm{ppy})_{2}(\mathrm{bpy})\right]^{+} @ 1$ materials not only have potential for practical lighting applications, but more importantly, this method of encapsulation of a luminescence-active molecular complex into a luminescent MOF to generate white light and to systematically tune the emission quality also represents a new approach to fabricate WLEDs with superior performance.

PL of $\mathbf{E u}^{3+}$ and $\mathrm{Tb}^{3+}$ co-doped emitters. Rare-earth ions (for example, $\mathrm{Eu}^{3+}, \mathrm{Tb}^{3+}$ and $\mathrm{Dy}^{3+}$ ) have been commonly used as dopants to obtain white-light emission. To evaluate their effect in $\mathbf{1}$, the samples of white-emitting $\mathrm{Eu}^{3+}$ and $\mathrm{Tb}^{3+}$ co-doped $\mathbf{1}$ were prepared (Supplementary Fig. S19) and their luminescent properties were studied. Under the excitation at $370 \mathrm{~nm}$, the MOF emission colour was fine-tuned to white by soaking $\mathbf{1}$ in DMF solutions containing nitrate salts of $\mathrm{Eu}^{3+}$ and $\mathrm{Tb}^{3+}$ in a molar ratio of 1:2. The corresponding CIE coordinates for this sample is $(0.36,0.32)$, approaching the coordinates of pure white light. Figure 6 shows photographs of the co-doped samples excited by a standard laboratory ultraviolet lamp $(365 \mathrm{~nm})$. The PL spectra of the co-doped samples were also collected under excitation at $370 \mathrm{~nm}$ (Fig. 6). These spectra feature a broad emission peak centred at $425 \mathrm{~nm}$ and several narrow-band emission peaks at $492,545,594$ and $618 \mathrm{~nm}$. The broad emission at $425 \mathrm{~nm}$ can be attributed to MLCT in 1 . The peaks at 492 and $545 \mathrm{~nm}$ are characteristic emissions of $\mathrm{Tb}$ cation. The maximal intensities at 594 and $618 \mathrm{~nm}$ are corresponding to the emissions of Eu cation. The white-light-emission quantum yield of this sample was measured at room temperature under $\lambda_{\mathrm{ex}}=370 \mathrm{~nm}$. A value of $11.3 \%$ was obtained which is significantly lower than that of $\mathrm{Ir}^{\mathrm{III}}$ encapsulated 1, assuming that the energy migrates through the same electronic levels located in the MOF structure to the doped lanthanide ions ${ }^{54}$. This result indicates that $\mathrm{Ir}^{\mathrm{III}}$-complex encapsulating method is likely a more effective approach to obtain high-efficient white-light-emitting MOF materials. On the other hand, introduction of $\mathrm{Eu}^{3+}$ or $\mathrm{Tb}^{3+}$ ions into 1 can lead to

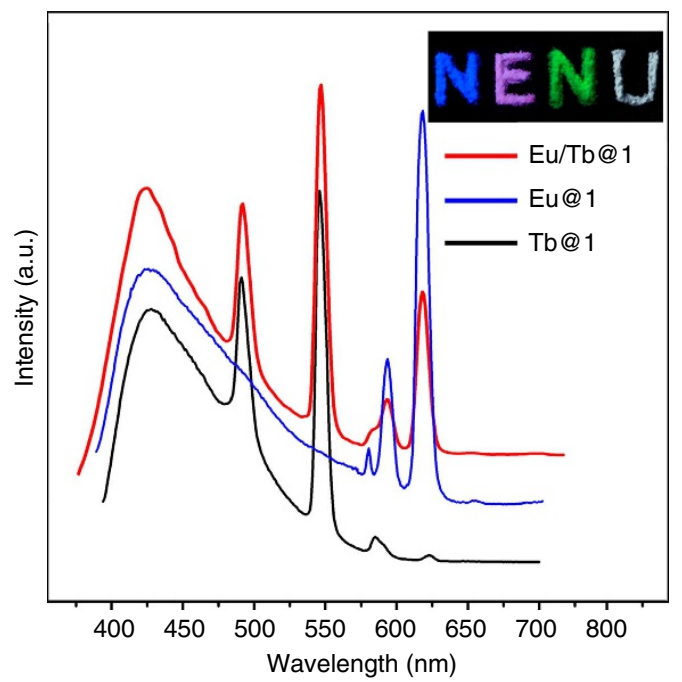

Figure 6 | PL spectra and optical photographs of lanthanide(III)-doped 1. Room temperature PL spectra of lanthanide(III)-doped $\mathbf{1}$ in the solid state upon excitation at $370 \mathrm{~nm}$ : black, Tb-doped 1; blue, Eu-doped 1; red, Eu- and Tb co-doped 1.The insets are the optical photographs of 1, Eu@1, $\mathrm{Tb} @ 1$ and $\mathrm{Eu} / \mathrm{Tb} @ 1$ excited under 365 nm ultraviolet lamps, corresponding to the letters $N, E, N$ and $U$, respectively. 
red and green light emissions. The corresponding PL spectra and the corresponding optical photographs are also given in Fig. 6.

\section{Discussion}

In this study, we have demonstrated that encapsulating an $\mathrm{Ir}^{\mathrm{III}}$ complex cation in the pores of an anionic MOF structure represents a convenient and efficient route to achieve white-light emission with high quantum yield and optimized colour quality. $\mathrm{H}_{6}$ TATPT was chosen as organic building block in the MOF synthesis, not only for its suitable length ${ }^{37,38}$ but also for its blue emission which was retained in the resultant framework. A cationic yellow-emitting $\mathrm{Ir}^{\mathrm{III}}$ complex, $\left[\operatorname{Ir}(\mathrm{ppy})_{2}(\mathrm{bpy})\right]^{+}$, was selected as the encapsulant based on the consideration of pore size and its complementary yellow emission.

$\left[\operatorname{Ir}(\mathrm{ppy})_{2}(\mathrm{bpy})\right]^{+}$was successfully introduced in the pore of the MOF host via encapsulating experiments. The encapsulated amount can easily be controlled and fine-tuned by varying exposure time and concentration. At an $\left[\operatorname{Ir}(\mathrm{ppy})_{2}(\mathrm{bpy})\right]^{+}$ concentration of $3.5 \mathrm{wt} \%$, high-quality white light was obtained and the resultant material possesses CIE coordinates $(0.31,0.33)$ that are very close to those of pure white light and good colour quality (CRI $\sim 80$ and CCT $\sim 5900 \mathrm{~K}$ ). In addition, this material also has the highest emission quantum yield (up to 20.4\%) compared with all MOFs reported to date ${ }^{12,27-33}$. The WLED assembly using an InGaAsN ultraviolet chip and this material can readily be fabricated. The CIE, CCT and CRI values are (0.30, $0.35), 84.5$ and $5409 \mathrm{~K}$, respectively, at a concentration of $3.8 \mathrm{wt} \%$ of Ir complex. Eu ${ }^{3+}$ and $\mathrm{Tb}^{3+}$ co-doped samples ( $\left.\mathrm{Tb} / \mathrm{Eu} @ \mathbf{1}\right)$ were also examined on their emission properties.

In summary, we have illustrated a judicious design strategy to generate white light by combining the independent emissions of the two components, namely blue emission from the MOF and yellow emission from the Ir complex. The strategy here is essentially the same as the RGB (red, green and blue) combination used in WLED industry to produce white light. We have demonstrated this in a well-controlled manner. We believe that this novel approach opens a new perspective for the development of high performance white phosphors. The new strategy, benefiting from a large number of available luminescent MOF matrix materials and a variety of highly fluorescent metal cationic complexes, offers a great flexibility and very many options in rational selection of matching MOF matrix and metalcomplex encapsulate, which, in turn, will facilitate the development of high performance white phosphors with systematically tunable emission properties and greatly enhance quantum efficiency.

\begin{abstract}
Methods
Materials and measurements. All reagents and solvents for the syntheses were purchased from commercial sources and used as received, except $\mathrm{H}_{6}$ TATPT. ICP spectroscopy was conducted on Agilent 7500a Inductively Coupled Plasma Mass Spectrometry (ICP-MS 7500). PXRD patterns were recorded on a Siemens D5005 diffractometer with $\mathrm{CuK} \alpha(\lambda=1.5418 \AA)$ radiation in the range $3-50^{\circ}$. EAs $(\mathrm{C}, \mathrm{H}$ and N) were performed on a Perkin-Elmer $240 \mathrm{C}$ elemental analyzer. Solvent ${ }^{1} \mathrm{H}$ NMR spectra were measured on BrukerAvance $500 \mathrm{MHz}$ with tetramethylsilane as the internal standard. TGA experiments were performed on a Perkin-Elmer TGA 7 analyzer heated from 50 to $800{ }^{\circ} \mathrm{C}$ under nitrogen gas atmosphere with a heating rate of $10^{\circ} \mathrm{C} \cdot \mathrm{min}^{-1}$. The emission spectra were recorded using the $\mathrm{F}-7000 \mathrm{FL}$ spectrophotometer. The PL quantum yields were measured using Hamamatsu multichannel analyzer c10027.
\end{abstract}

Synthesis of ligand $\mathbf{H}_{\mathbf{6}}$ TATPT. Cyanuric chloride $(1.84 \mathrm{~g}, 0.01 \mathrm{~mol})$ was added to $150 \mathrm{ml} \mathrm{H}_{2} \mathrm{O}$ and then was stirred at $0^{\circ} \mathrm{C}$ for $30 \mathrm{~min}$. After that a mixture of 2aminoterephthalic acid $(1.81 \mathrm{~g}, 0.01 \mathrm{~mol})$ and $\mathrm{NaOH}(1 \mathrm{~g}, 0.025 \mathrm{~mol})$ was added dropwise into the above solution and stirred at $<5^{\circ} \mathrm{C}$ for $1.5 \mathrm{~h}$. Then 2 -aminoterephthalic acid $(3.62 \mathrm{~g}, 0.02 \mathrm{~mol})$ sodium hydroxide solution was added and the reaction mixture was allowed to warm to room temperature. After string at room temperature for $2 \mathrm{~h}$, the mixture was heated slowly to boiling and refluxed for $3 \mathrm{~h}$. During this period, the $\mathrm{pH}$ of the mixture was maintained between 10 and 11 by the addition of sodium hydroxide solution. After cooling, the cloudy solution was filtered and the volume was increased to approximated $500 \mathrm{ml}$ by adding $300 \mathrm{ml}$ of water. The solution was acidified with concentrated hydrochloric acid whereupon a crystalline solid precipitated out. The mixture was allowed to cool to room temperature and filtered. After washing thoroughly with cold water, the product was dried in a vacuum oven and the yield was about $90 \% .{ }^{1} \mathrm{H}$ NMR ([D6]DMSO, $400 \mathrm{MHz}): \delta=8.12(3 \mathrm{H}), 8.47(6 \mathrm{H}), 9.67(3 \mathrm{H})$ and $13.0(6 \mathrm{H}) \mathrm{ppm}$. See Supplementary Figs S20 and S21 for high-resolution mass spectrometry and ${ }^{13} \mathrm{C}$-NMR data. The structure of $\mathrm{H}_{6}$ TATPT differs from $\mathrm{H}_{6}$ TDPAT reported previously in that the carboxylate groups are at 2,5 rather than 3,5 positions ${ }^{55}$.

Synthesis of compound 1. A mixture of $\mathrm{CdCl}_{2}(0.10 \mathrm{mmol}), \mathrm{H}_{6}$ TATPT $(0.12 \mathrm{mmol})$ and $6 \mathrm{ml}$ of $\mathrm{DMF} / \mathrm{CH}_{3} \mathrm{OH}(1: 1)$ was stirred for $10 \mathrm{~min}$. The mixture was then transferred to and, sealed in, a Teflon reactor $(18 \mathrm{ml})$ and heated at $120^{\circ} \mathrm{C}$ for $48 \mathrm{~h}$. After that, the mixture was cooled to room temperature at $5^{\circ} \mathrm{C} \cdot \mathrm{h}-1$ Colourless crystals of 1 were obtained (72.8\% yield based on TATPT). EA (\%) calculated for $\left[\left(\mathrm{CH}_{3}\right)_{2} \mathrm{NH}_{2}\right]_{15}\left[\left(\mathrm{Cd}_{2} \mathrm{Cl}\right)_{3}(\mathrm{TATPT})_{4}\right] \cdot 12 \mathrm{DMF} \cdot 18 \mathrm{H}_{2} \mathrm{O}$ $\left(\mathrm{C}_{174} \mathrm{H}_{288} \mathrm{~N}_{51} \mathrm{O}_{78} \mathrm{Cl}_{3} \mathrm{Cd}_{6}\right): \mathrm{C}, 40.71 ; \mathrm{H}, 5.60 ; \mathrm{N}, 13.93$; found: C, 40.68; H, 5.62; $\mathrm{N}, 13.88$.

Single-crystal X-ray diffraction study. Single-crystal X-ray diffraction data for $\mathbf{1}$ were recorded on a Bruker Apex CCD II area-detector diffractometer with graphite-monochromated $\mathrm{Mo}_{K \alpha}$ radiation $(\lambda=0.71073 \AA)$ at $293 \mathrm{~K}$. Absorption corrections were applied using multi-scan technique. Their structures were solved by direct method of SHELXS-97 and refined by full-matrix least-square techniques using the SHELXL-97 program. Because guest solvent molecules in channels were highly disordered and could not be modelled properly, thus the SQUEEZE routine of PLATON was applied to remove contributions to scattering from solvent molecules. The reported refinements are of guest-free structure by SQUEEZE routine. See Supplemetary Data 1 for further details.

Transition metal ion exchange experiments. Freshly prepared compound 1 $(20 \mathrm{mg})$ was soaked in DMF solutions of nitrate salts of $\mathrm{Cu}^{2+}, \mathrm{Co}^{2+}, \mathrm{Ni}^{2+}$ and $\mathrm{Zn}^{2+}(5 \mathrm{ml}, 0.1 \mathrm{mmol})$, respectively. After 5 days, the crystals were taken out of solution and washed with DMF to remove residual transition metal ions on the surface. The products were characterized by ICP and XRD and the results were listed in Supplementary Table S2 and Supplementary Fig. S6. The photographs of the samples containing transition metal ions are presented in Supplementary Fig. S5.

Procedure for encapsulating $\left[\operatorname{lr}(\mathbf{p p y})_{\mathbf{2}}(\mathbf{b p y})\right]^{+}$in $\mathbf{1}$. The samples of $\mathbf{1}(40 \mathrm{mg})$ were dipped in $10 \mathrm{ml}$ DMF solutions containing $1 \times 10^{-4} \mathrm{~mol} \mathrm{~L}^{-1}\left[\operatorname{Ir}(\text { ppy })_{2}(\mathrm{~b}-\right.$ py)] $\left[\mathrm{PF}_{6}\right]$ under stirring in $10 \mathrm{ml}$ sealed glass bottles. After $0.5,1,2,3,4,7$ and 10 days, the immersed samples were taken out and washed with DMF to remove residual Ir complex on the surface. The concentrations of encapsulated $\left[\operatorname{Ir}(\mathrm{ppy})_{2}(\mathrm{bpy})\right]^{+}$in $\left[\operatorname{Ir}(\mathrm{ppy})_{2}(\mathrm{bpy})\right]^{+} @ \mathbf{1}$ were measured by ICP experiment and the results were shown in Supplementary Table S3. The corresponding CIE coordinates were also calculated and listed in Supplementary Table S3.

Procedure for the preparation of lanthanide-doped compounds. Eu/Tb@1 sample was prepared by immersing freshly prepared compound $\mathbf{1}$ in DMF solutions of lanthanide nitrates with molar ratios of $1: 2$ (total amount $0.03 \mathrm{mmol}$ in $5 \mathrm{ml} \mathrm{DMF}$ ). After 7 days of soakage, the crystals were taken out of solution and washed with DMF to remove residual lanthanide ${ }^{\mathrm{III}}$ cations on the surface. A similar process was employed to prepare $\mathrm{Eu}^{3+}$ - or $\mathrm{Tb}^{3+}$-doped sample by soaking sample of 1 in DMF solutions of lanthanide nitrates of $\mathrm{Eu}^{3+}$ or $\mathrm{Tb}^{3+}(0.01 \mathrm{mmol}$ in $5 \mathrm{ml} \mathrm{DMF).} \mathrm{After} 5$ and 7 days of soakage, respectively, the crystals were washed with DMF to remove residual lanthanide ${ }^{\mathrm{III}}$ cations on the surface.

Fabrication of a simple WLED assembly. A WLED was fabricated by dripping the white phosphor of $3.8 \mathrm{wt} \%\left[\operatorname{Ir}(\mathrm{ppy})_{2}(\mathrm{bpy})\right]^{+} @ 1$ on an ultraviolet InGaAsN LED chip $\left(\lambda_{\mathrm{ex}}=370 \mathrm{~nm}\right)$. The colour parameters of the device including CIE, CCT and CRI were measured by Ocean Optics USB 4000 Spectrometer at a forward current of $150 \mathrm{~mA}$.

\section{References}

1. Reineke, S. et al. White organic light-emitting diodes with fluorescent tube efficiency. Nature 459, 234-238 (2009).

2. Wang, Q. \& Ma, D. Management of charges and excitons for high-performance white organic light-emitting diodes. Chem. Soc. Rev. 39, 2387-2398 (2010).

3. Furman, J. D., Warner, A. Y., Teat, S. J., Mikhailovsky, A. A. \& Cheetham, A. K. Tunable, ligand-based emission from inorganic - organic frameworks: a new approach to phosphors for solid state lighting and other applications. Chem. Mater. 22, 2255-2260 (2010). 
4. Green, W. H., Le, K. P., Grey, J., Au, T. T. \& Sailor, M. J. White phosphors from a silicate-carboxylate sol-gel precursor that lack metal activator ions. Science 276, 1826-1828 (1997).

5. Ki, W. \& Li, J. A semiconductor bulk material that emits direct white light. J. Am. Chem. Soc. 130, 8114-8115-8115 (2008).

6. Wada, Y., Sato, M. \& Tsukahara, Y. Fine control of red-green-blue photoluminescence in zeolites incorporated with rare-earth ions and a photosensitizer. Angew. Chem. Int. Ed. 45, 1925-1928 (2006).

7. Zhao, Y. S., Fu, H., Hu, F., Peng, A., Yang, W. \& Yao, J. Tunable emission from binary organic one-dimensional nanomaterials: an alternative approach to white-light emission. Adv. Mater. 20, 79-83 (2008).

8. Uchino, T. \& Yamada, T. White light emission from transparent SiO glass prepared from nanometer-sized silica particles. Appl. Phys. Lett. 85, 1164-1166 (2004)

9. Coppo, P., Duati, M., Kozhevnikov, V. N., Hofstraat, J. W. \& De Cola, L. White-light emission from an assembly comprising luminescent iridium and europium complexes. Angew. Chem. Int. Ed. 44, 1806-1810 (2005).

10. Ki, W., Li, J., Eda, G. \& Chhowalla, M. Direct white light emission from inorganic-organic hybrid semiconductor bulk materials. J. Mater. Chem. 20, 10676-10679 (2010)

11. Fang, X. M. et al. Tuning and enhancing white light emission of ii-vi based inorganic-organic hybrid semiconductors as single-phased phosphors. Chem. Mater. 24, 1710-1717 (2012).

12. Rao, X. et al. Color tunable and white light emitting Tb3 + and Eu3 + doped lanthanide metal-organic framework materials. J. Mater. Chem. 22, 3210-3214 (2012).

13. Wang, Y., Yu, J., Guo, M. \& Xu, R. [[Zn2(HPO4)4][Co(dien)2]]. $\mathrm{H}_{3} \mathrm{O}$ : a zinc phosphate with multidirectional intersecting helical channels. Angew. Chem. Int. Ed. 42, 4089-4092 (2003).

14. Wang, X. L. et al. Bottom-up synthesis of porous coordination frameworks: apical substitution of a pentanuclear tetrahedral precursor. Angew. Chem. Int. Ed. 48, 5291-5295 (2009).

15. Pan, M., Lin, X. -M., Li, G. -B. \& Su, C. -Y. Progress in the study of metalorganic materials applying naphthalene diimide (NDI) ligands. Coord. Chem. Rev. 255, 1921-1936 (2011).

16. Li, J.-R., Kuppler, R. J. \& Zhou, H. -C. Selective gas adsorption and separation in metal-organic frameworks. Chem. Soc. Rev. 38, 1477-1504 (2009).

17. Murray, L. J., Dincă, M. \& Long, J. R. Hydrogen storage in metal-organic frameworks. Chem. Soc. Rev. 38, 1294-1314 (2009).

18. Lee, J. et al. Metal-organic framework materials as catalysts. Chem. Soc. Rev. 38, 1450-1459 (2009).

19. Sun, C. Y. et al. Chiral nanoporous metal-organic frameworks with high porosity as materials for drug delivery. Adv. Mater. 23, 5629-5632 (2011)

20. Takashima, Y. et al. Molecular decoding using luminescence from an entangled porous framework. Nat. Comm. 2, 168-175 (2011).

21. Cui, Y. et al. A luminescent mixed-lanthanide metal-organic framework thermometer. J. Am. Chem. Soc. 134, 3979-3982 (2012).

22. Cui, Y., Yue, Y., Qian, G. \& Chen, B. Luminescent functional metal-organic frameworks. Chem. Rev. 112, 1126-1162 (2011).

23. Wang, M. -S. et al. A direct white-light-emitting metal - organic framework with tunable yellow-to-white photoluminescence by variation of excitation light. J. Am. Chem. Soc. 131, 13572-13573 (2009).

24. Wang, M. S. et al. A white-light-emitting borate-based inorganic-organic hybrid open framework. Angew. Chem. Int. Ed. 46, 3909-3911 (2007).

25. Sava, D. F., Rohwer, L. E., Rodriguez, M. A. \& Nenoff, T. M. Intrinsic broadband white-light emission by a tuned, corrugated metal-organic framework. J. Am. Chem. Soc. 134, 3983-3986 (2012)

26. He, J., Zeller, M., Hunter, A. D. \& Xu, Z.White Light Emission and Second Harmonic Generation from Secondary Group. Participation (SGP) in a coordination network. J. Am. Chem. Soc. 134, 1553-1559 (2012).

27. Huang, Y. T., Lai, Y. C. \& Wang, S. L. Intrinsic green phosphor containing a $\left\{\mathrm{Y}_{5} \mathrm{O}_{22}\right\}$ pentamer unit and a carbonate ligand generated in situ from squaric acid. Chem. Eur. J. 18, 8614-8616 (2012).

28. Li, S. -M., Zheng, X. -J., Yuan, D. -Q., Ablet, A. \& Jin, L. -P. In situ formed white-light-emitting lanthanide-zinc-organic frameworks. Inorg. Chem. 51, 1201-1203 (2012).

29. Liu, K. et al. Room-temperature synthesis of multi-morphological coordination polymer and tunable white-light emission. Cryst. Growth Des. 10, 16-19 (2009).

30. Costa, R. D. et al. Luminescent ionic transition-metal complexes for lightemitting electrochemical cells. Angew. Chem. Int. Ed. 51, 8178-8211 (2012).

31. Deng, H. et al. Large-pore apertures in a series of metal-organic frameworks. Science 336, 1018-1023 (2012).

32. Brinkmann, M. et al. Correlation between molecular packing and optical properties in different crystalline polymorphs and amorphous thin films of mer-tris (8-hydroxyquinoline) aluminum (III). J. Am. Chem. Soc. 122, 5147-5157 (2000).
33. Chen, B., Eddaoudi, M., Hyde, S., O’keeffe, M. \& Yaghi, O. Interwoven metalorganic framework on a periodic minimal surface with extra-large pores. Science 291, 1021-1023 (2001).

34. Li, B. et al. Enhanced binding affinity, remarkable selectivity, and high capacity of $\mathrm{CO}_{2}$ by dual functionalization of a rht-type metal-organic framework. Angew. Chem. Int. Ed. 51, 1412-1415 (2012).

35. McGarrah, J. E., Kim, Y. -J., Hissler, M. \& Eisenberg, R. Toward a molecular photochemical device: a triad for photoinduced charge separation based on a platinum diimine bis (acetylide) chromophore. Inorg. Chem. 40, 4510-4511 (2001).

36. Roushan, M., Zhang, X. \& Li, J. Solution-processable white-light-emitting hybrid semiconductor bulk materials with high photoluminescence quantum efficiency. Angew. Chem. Int. Ed. 51, 436-439 (2012).

37. Sun, C. Y. et al. Solvatochromic behavior of chiral mesoporous metal-organic frameworks and their applications for sensing small molecules and separating cationic dyes. Chem. Eur. J. 19, 3639-3645 (2013).

38. Perry, I. v. J. J., Perman, J. A. \& Zaworotko, M. J. Design and synthesis of metal-organic frameworks using metal-organic polyhedra as supermolecular building blocks. Chem. Soc. Rev. 38, 1400-1417 (2009).

39. Spek, A. Single-crystal structure validation with the program PLATON. J. Appl. Crystallogr. 36, 7-13 (2003).

40. Wei, Y., Yu, Y. \& Wu, K. Highly stable five-coordinated Mn (II) polymer [Mn (Hbidc) $] \mathrm{n}($ Hbidc $=1 \mathrm{H}$-Benzimidazole-5, 6-dicarboxylate): crystal structure antiferromagnetic property, and strong long-lived luminescence. Cryst. Growth Des. 8, 2087-2089 (2008)

41. Allendorf, M. D., Bauer, C. A., Bhakta, R. K. \& Houk, R. J. T. Luminescent metal-organic frameworks. Chem. Soc. Rev. 38, 1330-1352 (2009).

42. Wang, G. -H., Li, Z. -G., Jia, H. -Q., Hu, N. -H. \& Xu, J. -W. Metal-organic frameworks based on the pyridine-2, 3-dicarboxylate and a flexible bispyridyl ligand: syntheses, structures, and photoluminescence. Cryst. Eng. Comm. 11, 292-297 (2009).

43. Wang, L. et al. Highly efficient and color-stable deep-blue organic lightemitting diodes based on a solution-processible dendrimer. Adv. Mater. 21, 4854-4858 (2009).

44. Stylianou, K. C. et al. A guest-responsive fluorescent 3D microporous metal - organic framework derived from a long-lifetime pyrene core. J. Am. Chem. Soc. 132, 4119-4130 (2010).

45. Wang, R. J. et al. Highly efficient orange and white organic light-emitting diodes based on new orange iridium complexes. Adv. Mater. 23, 2823-2827 (2011).

46. Garces, F., King, K. \& Watts, R. Synthesis, structure, electrochemistry, and photophysics of methyl-substituted phenylpyridine ortho-metalated iridium (III) complexes. Inorg. Chem. 27, 3464-3471 (1988).

47. Tsuboyama, A. et al. Homoleptic cyclometalated iridium complexes with highly efficient red phosphorescence and application to organic light-emitting diode. J. Am. Chem. Soc. 125, 12971-12979 (2003).

48. Costa, R. D. et al. Archetype cationic iridium complexes and their use in solid state light-emitting electrochemical cells. Adv. Funct. Mater. 19, 3456-3463 (2009).

49. Polo, A. S., Itokazu, M. K., Frin, K. M., de Toledo Patrocínio, A. O. \& Murakami Iha, N. Y. Light driven trans-to-cis isomerization of stilbene-like ligands in fac- $[\operatorname{Re}(\mathrm{CO}) 3(\mathrm{NN})($ trans-L) + and luminescence of their photoproducts. Coord. Chem. Rev. 250, 1669-1680 (2006).

50. Marti, A. A., Rivera, N., Soto, K., Maldonado, L. \& Colon, J. L. Intercalation of $\mathrm{Re}($ phen)(CO) $3 \mathrm{Cl}$ into zirconium phosphate: a water insoluble inorganic complex immobilized in a highly polar rigid matrix. Dalton. Trans. 7, 1713-1718 (2007).

51. Wrighton, M. \& Morse, D. L. Nature of the lowest excited state in tricarbonylchloro-1,10-phenanthrolinerhenium(I) and related complexes. J. Am. Chem. Soc. 96, 998-1003 (1974).

52. Chang, Y. -L. et al. Highly efficient warm white organic light-emitting diodes by triplet exciton conversion. Adv. Funct. Mater. 23, 705-712 (2013).

53. Sohn, H., Sailor, M. J., Magde, D. \& Trogler, W. C. Detection of nitroaromatic explosives based on photoluminescent polymers containing metalloles. J. Am. Chem. Soc. 125, 3821-3830 (2003).

54. An, J., Shade, C. M., Chengelis-Czegan, D. A., Petoud, S. p. \& Rosi, N. L. Zinc-adeninate metal - organic framework for aqueous encapsulation and sensitization of near-infrared and visible emitting lanthanide cations. J. Am. Chem. Soc. 133, 1220-1223 (2011).

55. Li, B. et al. Enhanced binding affinity, remarkable selectivity, and high capacity of $\mathrm{CO}_{2}$ by dual functionalization of a rht-type metal-organic framework. Angew. Chem. Int. Ed. 51, 1412-1415 (2012)

\section{Acknowledgements}

This work was financially supported by the NSFC of China (Nos. 21001022, 21171033, 21131001 and 21222105), The Foundation for Author of National Excellent Doctora Dissertation of P.R. China (No. 201022), National Basic Research Program of China 
(973 Program-2009CB623605), SRFDP and RGC ERG Joint Research Program (No. 20120043140001). The RU team acknowledges the support of National Science Foundation (DMR-1206700).

\section{Author contributions}

C.-Y.S., Z.-M.S., X.-L.W. and J.L. designed the experiments, interpreted the data and cowrote the paper. C.-Y.S., X.Z. and D.-X.Z. carried out synthesis, optical measurements and data analysis. C.Q., P.L., G.-G.S., K.-Z.S. and H.W. performed other characterization experiments and related analyses. All authors discussed and commented on the manuscript.

\section{Additional information}

Accession codes: The X-ray crystallographic coordinates for complex 1 have been deposited at the Cambridge Crystallographic Data Centre (CCDC), under deposition number CCDC 916964. These data can be obtained free of charge from the Cambridge Crystallographic Data Centre via www.ccdc.cam.ac.uk/ data_request/cif.

Supplementary Information accompanies this paper at http://www.nature.com/ naturecommunications

Competing financial interests: The authors declare no competing financial interests.

Reprints and permission information is available online at http://npg.nature.com/ reprintsandpermissions/

How to cite this article: Sun, C-Y. et al. Efficient and tunable white-light emission of metal-organic frameworks by iridium-complex encapsulation. Nat. Commun. 4:2717 doi: 10.1038/ncomms3717 (2013).

(C) $($ (1) This work is licensed under a Creative Commons Attributioncc. No No No Nommercial-NoDerivs 3.0 Unported License. To view a copy of this license, visit http://creativecommons.org/licenses/by-nc-nd/3.0/ 